\title{
KOMPETENSI MAHASISWA PADA PEMBELAJARAN MATEMATIKA MENGGUNAKAN GEOMETER'S SKETCHPAD DENGAN AUTHENTIC ASSESSMENT
}

\author{
Mohammad Syaifuddin*, Reni Dwi Susanti, Rizal Dian Azmi \\ FKIP Universitas Muhammadiyah Malang, Indonesia \\ Email: drm.syaifuddin@gmail.com \\ *Corresponden Author
}

\begin{abstract}
ABSTRAK
Penelitian ini bertujuan untuk menganalisis kompetensi matematika mahasiswa pada pembelajaran menggunakan Geometer's Sketchpad dengan authentic assessment baik dari aspek sikap, pengetahuan, dan keterampilan. Jenis penelitian ini adalah kombinasi penelitian kualitatif dan kuantitatif. Subjek penelitian adalah 92 mahasiswa yang mengambil mata kuliah geometri transformasi, dengan 48 dan 44 mahasiswa dari kelas eksperiman dan kontrol. Metode pengumpulan data menggunakan tes, observasi dan angket. Metode kualitatif deskriptif digunakan untuk menganalisis data sikap dan keterampilan mahasiswa dalam menggunakan Geometer's Sketchpad, dan uji t berbantuan SPSS digunakan untuk menganalisis perbedaan pemahaman konsep matematika mahasiswa. Hasil penelitian menunjukkan bahwa sikap, respon, dan keterampilan mahasiswa pada pembelajaran menggunakan Geometer's Sketchpad berkategori baik, dimana Geometer's Sketchpad sangat membantu mahasiswa dalam memahami mata kuliah gemoetri transformasi dan terampil menggunakannya. Kompetensi mahasiswa yang menggunakan Geometer's Sketchpad dengan authentic assesssment lebih baik dari kompetensi mahasiswa yang tidak menggunakan Geometer's Sketchpad. Diharapkan Geometer's Sketchpad dapat digunakan pada penelitian lainnya sehingga kompetensi mahasiswa menjadi lebih baik.
\end{abstract}

Kata Kunci: Authentic Assessment; Geometer's Sketchpad; Keterampilan; Pengetahuan; Sikap.

\begin{abstract}
This research aimed to analyze the mathematical competence of students in learning using Geometer's Sketchpad with authentic assessment both in aspects of attitudes, knowledge, and skills. This type of research employed a combination of qualitative and quantitative research on The One-Shot Case Study. The research subjects were 92 students undergoing analytic geometry transformation courses, with 48 and 44 students formed the experimental and control classes respectively. The data collection methods employed test, observation and questionnaire. Descriptive qualitative methods were used to analyze student attitude and skill data in using Geometer's Sketchpad, and SPSS-assisted t-tests were used to analyze differences in students' mathematical understanding of concepts. The results showed that students' attitudes, responses, and skills in learning using Geometer's Sketchpad were categorized as good, where Geometer's Sketchpad really helped students to understand geometry of transformation and use them skillfully. The competencies of students who use Geometer's Sketchpad with authentic assessment were better than the competencies of students who are not using Geometer's Sketchpad. It is purposed that the Geometer's Sketchpad can be used in other studies so that student competencies become better.
\end{abstract}

Keywords: Authentic Assessment; Geometer's Sketchpad; Skills; Knowledge; Attitude.

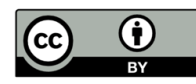

How to cite: Syaifuddin, M., Susanti, R., \& Azmi, R. (2020). Kompetensi Mahasiswa Pada Pembelajaran Matematika Menggunakan Geometer's Sketchpad dengan Authentic Assessment. JINoP (Jurnal Inovasi Pembelajaran), 6(1). doi:https://doi.org/10.22219/jinop.v6i1.5014 


\section{PENDAHULUAN}

Perkembangan ilmu pengetahuan dan teknologi telah membawa berbagai perubahan di kehidupan sehari-hari. Banyak pula pembicaraan yang telah di ungkapkan terkait dengan penggunaan Teknologi Informasi dan Komunikasi terutama dalam dunia pendidikan (Bakar, Tarmizi, Ayub, \& Yunus, 2009). Berbagai aplikasi untuk ilmu pengetahuan dan teknologi telah tersedia dan dapat digunakan sebagai penunjang dalam memenuhi kebutuhan sehari-hari. Keadaan seperti ini menunjukkan bahwa betapa pentingnya penguasaan ilmu pengetahuan dan teknologi. Tidak hanya itu, dengan perkembangan ilmu pengetahuan dan teknologi juga mendorong manusia agar mampu berkontribusi dan memiliki kesempatan yang lebih baik dalam menghadapi persaingan di kehidupan nyata.

Salah satu bidang ilmu pengetahuan yang berkembang sangat pesat adalah dalam bidang pendidikan, misalnya dalam pengembangan media pembelajaran atau penggunaan software dalam membantu proses pembelajaran. Penggunaan media pembelajaran memiliki kontribusi dalam meningkatkan mutu dan kualitas pembelajaran (Kintoko, Sujadi, \& Saputro, 2015). Teknologi Informasi dapat digunakan untuk mengajar, memfasilitasi belajar, membantu mahasiswa belajar, dan untuk meningkatkan efektivitas pelaksanaan tugas akademik (Becker, 1991).

Matematika merupakan salah satu dari beberapa bidang ilmu yang banyak menggunakan software sebagai visualisasi untuk media pembelajaran. Salah satu software yang bisa digunakan yaitu Geometer's Sketchpad. Geometer's Sketchpad adalah salah satu perangkat lunak matematika yang memberi kesempatan bagi pendidik dan peserta didik untuk menggunakan, mengakses, memvisualisasikan, dan menciptakan representasi grafis (Khairiree, 1994). Inilah salah satu alasan mengapa diperlukan suatu cara mengubah sistem pembelajaran matematika (Eu, 2013). Penggunaan Geometer's Sketchpad tersebut misalnya dalam hal pemahaman konsep dalam pembelajaran matematika. Karena matematika sangat teknis, item penilaian menjadi hal yang mendasar dalam proses penilaian (Wu, 2012). Syamsuduha (2011) dalam penelitiannya menyatakan bahwa terdapat pengaruh pembelajaran kooperatif berbantuan program Geometer's Sketchpad terhadap kemampuan berpikir kritis matematik. Hasil tersebut sejalan dengan pendapat ahli bahwa penggunaan software dapat berpengaruh baik pada kegiatan pembelajaran terutama dalam bidang matematika (Dimakos \& Zarani, 2010).

Penilaian adalah kegiatan yang terintegrasi dengan pembelajaran. Ini juga merupakan proses, yang membantu dalam mengembangkan pembelajaran mahasiswa (Azim \& Khan, 2012). Terkait dengan proses penilaian, evaluasi pembelajaran diterapkan untuk mengetahui prestasi peserta didik dan mendiagnosis hasil pembelajaran, dan memainkan peran penting dalam meningkatkan kualitas pembelajaran (Jahanian, 2012). Apabila peserta didik dapat mengetahui kemajuan dan perkembangan dirinya, maka peserta didik tersebut dapat mengatur belajarnya dengan menentukan langkah-langkah kegiatan belajar. Namun kenyataan di lapangan, penilaian hasil belajar yang dilakukan hanya dari segi pengetahuan. Pendidik mengukur keberhasilan belajar mahasiswa dengan tes tertulis. Penilaian hanya terfokus pada kompetensi pengetahuan, sedangkan sikap dan keterampilan selama proses pembelajaran tidak dilihat.

Penilaian yang dianjurkan untuk digunakan adalah penilaian autentik (Frey, Schmitt, \& Allen, 2012). Kurikulum 2013 juga menyatakan bahwa penilaian yang sebaiknya digunakan adalah penilaian autentik. Penilaian tersebut mencakup 
kompetensi sikap, keterampilan dan pengetahuan selama proses pembelajaran. Penilaian otentik sering dianggap sebagai alat yang produktif untuk meningkatkan keterlibatan, pembelajaran, dan kepercayaan pada mahasiswa (Hodgman, 2014). Section \& Alam (2010) meneliti tentang pelaksanaan penilaian otentik pada pendidikan tinggi melalui metodologi kualitatif termasuk wawancara, analisis dokumen, dan observasi kelas. Mereka menemukan strategi bahwa penilaian harus terkait erat dengan pengajaran dan pembelajaran serta menyimpulkan bahwa penilaian otentik lebih baik digunakan. Pendidik harus merancang instrumen penilaian sesuai dengan kompetensi yang ingin dicapai dari mata pelajaran dan dapat diaplikasikan dalam kehidupan sehari-hari.

Penelitian terkait dengan penggunaan Geometer's Sketchpad pada pembelajaran lebih banyak untuk mengukur kompetensi pengetahuan, sedangkan pengukuran kompetensi sikap dan keterampilan utamanya mengukur kinerja mahasiswa dalam menggunakan media Geometer's Sketchpad masih jarang dilakukan. Sepeti penelitian yang dilakukan oleh Idris $(2007,2009)$ menemukan bahwa penggunaan Geometer's Sketchpad dan model Van Hiele sangat berguna bagi guru matematika, utamanya dalam perencanaan pembelajaran Geometri. Penggunaan Geometer's Sketchpad berpengaruh positif terhadap prestasi pembelajaran Fungsi Graph, dan sikap terhadap pembelajaran Fungsi Graph meningkat (Eu, 2013). Hasil penelitian Tieng \& Eu (2014) menemukan bahwa tidak ada korelasi antara literasi siswa dalam menggunakan ICT dan kemampuan berpikir geometri Van Hiele setelah menggunakan Geometer's Sketchpad.

Pada penelitian ini menekankan pada penggunaan authentic assessment yang membedakan dengan penelitian sebelumnya. Oleh sebab itu penelitian tentang penggunaan Geometer's Sketchpad dengan authentic assessment perlu dilakukan. Penerapan authentic assessment pada penelitian ini untuk mengukur kompetensi mahasiswa secara menyeluruh yaitu sikap, pengetahuan, dan keterampilan.

Berdasarkan uraian latar belakang tersebut maka tujuan penelitian ini adalah mendeskripsikan kompetensi sikap dan keterampilan mahasiswa pada pembelajaran matematika menggunakan Geometer's Sketchpad dengan Authentic Assessment, dan menganalis adakah perbedaan pemahaman konsep geometeri transformasi mahasiswa antara penggunaan Geometer's Sketchpad dengan Authentic Assessment dengan tanpa menggunakan Geometer's Sketchpad dengan Authentic Assessment.

Berdasarkan kajian teori dan beberapa penelitian yang relevan, maka hipotesis penelitian ini adalah pemahaman konsep geometri transformasi mahasiswa pada pembelajaran menggunakan Geometer's Sketchpad dengan Authentic Assessment lebih baik dari pemahaman konsep geometri transformasi mahasiswa yang tidak menggunakannya.

\section{METODE}

Penelitian ini menggunakan kombinasi penelitian kualitatif dan kuantitatif. Kelompok subjek diberikan suatu perlakuan tertentu dan kemudian dilakukan pengukuran hasilnya. Subjek penelitian adalah 92 mahasiswa yang mengambil mata kuliah geometri transformasi, dengan 48 dan 44 mahasiswa dari kelas eksperiman dan kontrol.

Metode pengumpulan data yang digunakan pada penelitian ini adalah tes, observasi, dan angket. Instrumen penelitian yang digunakan dalam penelitian ini adalah tes berbentuk uraian untuk mengukur pemahaman konsep baik untuk kelas control maupun kelas eksperimen. Angket digunakan untuk mengukur sikap mahasiswa, dan

Mohammad Syaifuddin, Reni Dwi Susanti, Rizal Dian Azmi, Kompetensi Mahasiswa Pada Pembelajaran Matematika Menggunakan Geometer's Sketchpad dengan Authentic Assessment 
lembar observasi digunakan untuk mengukur keterampilan mahasiswa dalam menggunakan Geometer's Sketchpad.

Analisis data dilakukan dengan dua metode, yaitu metode kualitatif dan kuantitatif. Analisis kualitatif, digunakan untuk menganalisis penilaian sikap dan keterampilan yang dilakukan dengan beberapa tahap reduksi data, menyajikan data, dan penarikan kesimpulan. Independent sampel t-test dengan interval kepercayaan 95\% digunakan untuk menguji perbedaan pemahaman konsep geometri transformasi antara kelas eksperimen yang menggunakan Geometer's sketchpad dengan authentic assessment dan kelas control yang tidak menggunakan Geometer's sketchpad dengan authentic assessment.

\section{HASIL DAN PEMBAHASAN}

Penggunaan Geometer's Sketchpad pada pemahaman konsep matematika dengan menggunakan Authentic Assessment.

Kegiatan penelitian dilakukan terhadap dua kelas, yaitu kelas A sebagai kelas kontrol dan kelas B sebagai kelas eksperimen. Kelas A mendapatkan pembelajaran tanpa menggunakan Geometer's Sketchpad. Pembelajaran dilakukan dengan pembelajaran langsung melalui pemberian penjelasan materi dengan menggunakan gambar pada whiteboard. Sedangkan kelas B mendapatkan pembelajaran dengan Geometer's Sketchpad. Pada kelas ini dilakukan pembelajaran melalui pemberian penjelasan materi yang dikombinasikan dengan menggunakan Geometer's Sketchpad.

Pada kelas dengan menggunakan Geometer's Sketchpad, kompetensi mahasiswa diukur menggunakan authentic assessment meliputi aspek sikap, pengetahuan, dan keterampilan. Pada aspek pengetahuan, kompetensi mahasiswa dilihat dari pemahaman konsep geometri transformasi.

Dalam proses pelaksanaan pembelajaran di dalam kelas, ketika pendidik menyampaikan materi tentang geometri transformasi, para peserta yang dalam hal ini adalah mahasiswa banyak yang masih tidak merespon apa yang dijelaskan oleh pendidik. Akan tetapi setelah pendidik memberikan tutorial tentang Geometer's Sketchpad terlihat sebagian besar mahasiswa sangat memperhatikan. Demikian pula ketika pendidik memberikan materi dengan media pembelajaran geometri transformasi yang telah dibuat menggunakan Geometer's Sketchpad. Ini mencerminkan bahwa para pendidik lebih antusias dengan media yang dapat menjelaskan materi geometri transformasi dari pada memperhatikan pendidik yang hanya menjelaskan teori saja tanpa menggunakan suatu media.

\section{Penilaian Pemahaman Konsep}

Penilaian pemahaman konsep ini dilakukan dengan cara memberikan 4 soal uraian. Hasil untuk penilaian kognitif mahasiswa ditunjukkan oleh Gambar 1. 


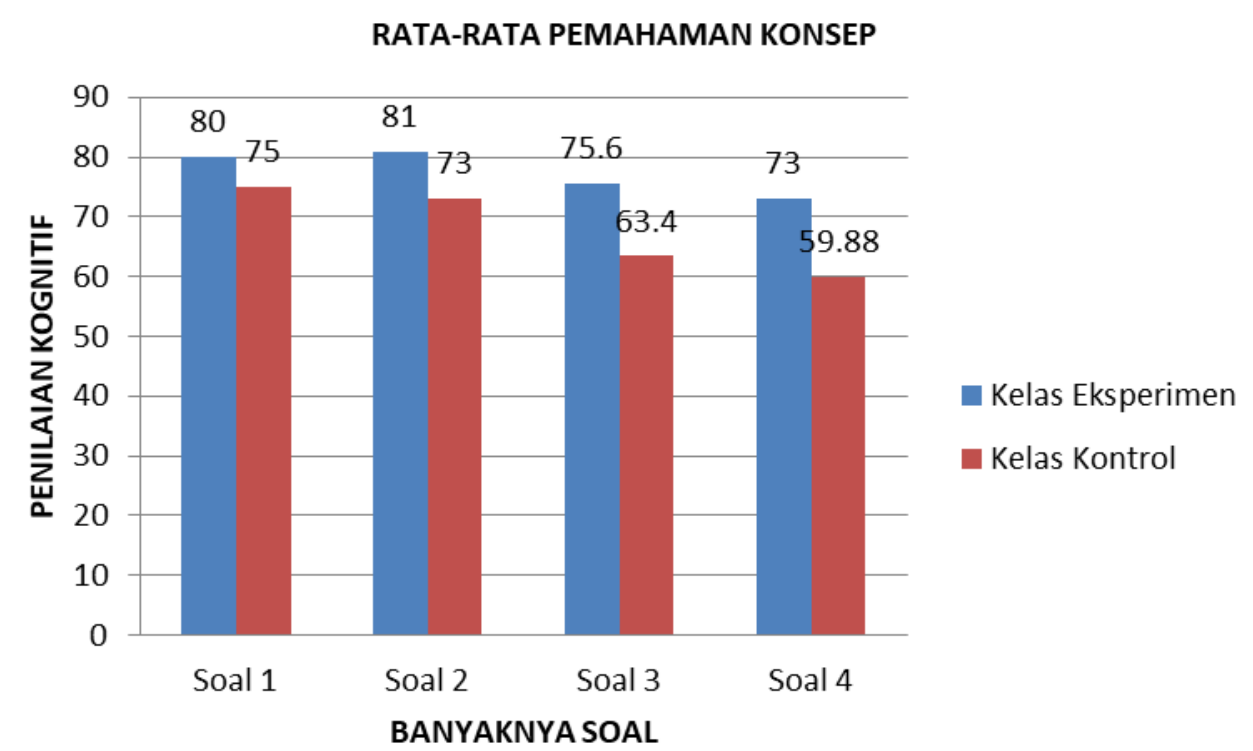

Gambar 1. Rata-rata nilai Geometri Transformasi kelas eksperimen

Berdasarkan Gambar 1 menunjukkan bahwa soal 3 dan 4 lebih sulit dari soal 1 dan 2 baik pada mahasiswa kelompok eksperimen dan control. Nilai mahasiswa dari kelompok eksperimen lebih tinggi dari mahasiswa kelas control untuk setiap soal. Ini menunjukkan bahwa penggunaan Geometer's Sketchpad memberikan kemudahan bagi mahasiswa untuk memahami konsep lebih baik.

Hasil analisis menggunakan Independent Sampel t-test disajikan dalam Tabel 1.

Tabel 1. Hasil analisis Independent Sampel t-test.

\begin{tabular}{|c|c|c|c|c|c|c|c|c|}
\hline \multicolumn{5}{|c|}{$\begin{array}{l}\text { Levene's Test } \\
\text { for Equality of } \\
\text { Variances }\end{array}$} & \multicolumn{4}{|c|}{ t-test for Equality of Means } \\
\hline & & & & & & & & $\begin{array}{c}95 \% \\
\text { Confidence } \\
\text { Interval of the } \\
\text { Difference }\end{array}$ \\
\hline $\mathrm{F}$ & & Sig. & $\mathrm{t}$ & df & $\begin{array}{c}\text { Sig. } \\
(2- \\
\text { tailed })\end{array}$ & $\begin{array}{c}\text { Mean } \\
\text { Difference }\end{array}$ & $\begin{array}{l}\text { Std. Error } \\
\text { Difference }\end{array}$ & Lower Upper \\
\hline Equal variances assumed & .751 & .388 & 3.057 & 90 & .003 & 9.578 & 3.133 & $3.353 \quad 15.802$ \\
\hline Equal variances not assum & & & 3.049 & 38.117 & .003 & 9.578 & 3.141 & 3.33515 .820 \\
\hline
\end{tabular}

Tabel 1 menunjukkan bahwa nilai sig. pada uji t untuk nilai dengan varian yang diasumsikan sama dan tidak sama kurang dari 5\%. Oleh karena itu hipotesis nol ditolak dan menerima hipotesis alternatif. Artinya terdapat perbedaan yang signifikan nilai geometri transformasi mahasiswa yang mendapatkan Geometer's Sketchpad dan yang tidak mendapatkannya dengan tingkat kepercayaan 95\%.

Berdasarkan nilai kedua kelompok dapat dinyatakan bahwa nilai geometri tranformasi mahasiswa yang menggunakan Geometer's Sketchpad lebih baik dari nilai

Mohammad Syaifuddin, Reni Dwi Susanti, Rizal Dian Azmi, Kompetensi Mahasiswa Pada Pembelajaran Matematika Menggunakan Geometer's Sketchpad dengan Authentic Assessment 
mahasiswa yang tidak menggunakannya. Hasil ini menggambarkan bahwa penggunaan Geometer's Sketchpad sangat membantu mahasiswa memahami materi geometri transformasi.

Hasil penelitian ini senada dengan penelitian yang dilakukan oleh Hodianto \& Danar (2019) yaitu pembelajaran dengan menggunakan Geometer's Sketchpad memberi pengaruh yang significant terhadap pemahaman konsep mahasiswa dalam belajar. Selain itu penelitian yang dilakukan oleh Asmawati (2019) juga menyatakan bahwa pembelajaran yang dilakukan dengan menggunakan Geometr's Sketchpad dapat meningkatkan keterampilan pemahaman konseptual dalam transformasi materi, dan dapat meningkatkan aktivitas dalam pembelajaran.

\section{Penilaian Afektif}

Penilaian sikap dilakukan ketika kegiatan observasi berlangsung dan juga penilaian diri terkait dengan penerapan Geometer's Sketchpad. Sikap yang ditujukkan mahasiswa ketika kegiatan pembelajaran berlangsung adalah dengan Geometer's Sketchpad mahasiswa lebih bersemangat dalam mengikuti perkuliahan dan lebih mudah dalam memahami konsep yang dimaksud dalam materi tersebut. Selain itu dalam memahami konsep dot product dan cross product menggunakan Geometer's Sketchpad mahasiswa lebih mudah memahami. Mahasiswa akan lebih mudah memahami materi geometri jika visualisasi langsung menggunakan gambar. Dengan Geometer's Sketchpad visualisasi dapat langsung dilakukan dengan tiga dimensi sehingga pergerakan sudut bisa langsung dipahami dan diketahui oleh mahasiswa.

Dalam hal ini digunakan penilaian diri untuk afektif assesment. Penilaian diri digunakan untuk melihat sikap mahaiswa mulai dari pemberian soal sampai pada penggunaan Geometer's Sketchpad. Penilaian diri ini digunakan guna melihat sikap mahasiswa terkait dengan penggunaan media pembelajaran Geometer's Sketchpad pada materi Geometri transformasi. Adapun hasil dari penilaian diri dapat dilihat pada tabel 2 .

\section{Tabel 2. Hasil Analisis Sikap Mahasiswa}

\begin{tabular}{|c|c|c|c|}
\hline No & Aspek Penilaian & $\%$ & Kategori \\
\hline 1 & $\begin{array}{l}\text { Pembelajaran geometri transformasi menggunakan Geometer's Sketchpad } \\
\text { menyenangkan }\end{array}$ & 83,33 & Baik \\
\hline 2 & $\begin{array}{l}\text { Media pembelajaran Geometer's Sketchpad dapat membantu saya dalam mempelajari } \\
\text { geometri transformasi }\end{array}$ & 78,2 & Sangat baik \\
\hline 3 & Selalu berusaha untuk mempelajari konsep-konsep dalam geometri transformasi & 83,33 & Baik \\
\hline 4 & Mampu mengerjakan soal yang diberikan & 75 & Baik \\
\hline 5 & Dengan bantuan Geometer's Sketchpad saya mampu mengerjakan soal yang diberikan & 73,8 & Baik \\
\hline 6 & Bersemangat dalam mengerjakan soal yang diberikan & 85 & Baik \\
\hline 7 & $\begin{array}{l}\text { Soal yang diberikan menarik sehingga menambah keinginan saya untuk menemukan } \\
\text { konsep dasarnya }\end{array}$ & 77,3 & Baik \\
\hline 8 & Selalu ingin bertanya selama pembelajaran berlangsung & 82 & Sangat baik \\
\hline 9 & Dengan pembelajaran seperti ini, saya dituntut untuk aktif dalam kelas & 87,4 & Sangat baik \\
\hline 10 & $\begin{array}{l}\text { Dengan pembelajaran seperti ini membuat saya bersemangat untuk belajar geometri } \\
\text { transformasi }\end{array}$ & 80 & Sangat baik \\
\hline 11 & Dosen selalu membimbing dan mengarahkan saya selama proses pembelajaran & 77,3 & Baik \\
\hline 12 & $\begin{array}{l}\text { Bersemangat untuk mengikuti pembelajaran di kelas geometri transformasi dengan } \\
\text { media Geometer's Sketchpad }\end{array}$ & 83,33 & Sangat baik \\
\hline
\end{tabular}

JINoP (Jurnal Inovasi Pembelajaran),Volume 6, Nomor 1, Mei 2020, hal 41-49 
Analisis sikap yang diperoleh dari respon penilaian diri dapat dilihat pada Tabel 1 . Berdasarkan data tersebut diperoleh bahwa mahasiswa merasa sangat bersemangat dalam kegiatan pembelajaran. Oleh karena pembelajaran dilakukan dengan interaktif maka menuntut mahasiswa untuk aktif dalam kegiatan pembelajaran. Penerapan media pembelajaran Geometer's Sketchpad sangat membantu mahasiswa dalam memahami mata kuliah gemoetri transformasi, dimana prosentase yang didapatkan berdasarkan penilaian diri mahasiswa adalah 78,2\% untuk penggunaan media pembelajaran, $87,4 \%$ untuk keaktifan mahasiswa dalam kegiatan pembelajaran dan $80 \%$ untuk respon baik dari mahasiswa dan bersemangat dalam mempelajari geometri transformasi.

Hasil penelitian ini menunjukkan bahwa sikap mahasiswa pada pembelajaran geometri transformasi menggunakan Geometer's Sketchpad sangat baik. Hal ini ditunjukkan oleh nilai sangat baik pada semangat dan keinginan siswa untuk belajar. Hasil ini sejalan dengan penelitian Phonguttha, Tayraukham, dan Nuangchalerm (2008) yang menyatakan bahwa siswa yang melakukan pembelajaran berkelompok dengan menggunakan Geometer's Sketchpad sebagai media memiliki sikap yang lebih baik dibandingkan dengan siswa yang melakukan pembelajaran secara konvensional. Hal yang sama dikemukakan Leong Kwan Eu (2013) bahwa siswa lebih bersikap positif pada saat pelajaran yang menggunakan Geometer's Sketchpad, dikarenakan mereka merasa senang mempelajari grafik fungsi yang diinterpretasikan dengan sangat baik pada Geometer's Sketchpad.

\section{Penilaian Keterampilan}

Data hasil penelitian keterampilan mahasiswa dalam menggunakan Geometer's Sketchpad disajikan pada Tabel 3 berikut.

Tabel 3. Analisis Penilaian Keterampilan

\begin{tabular}{lc}
\hline \multicolumn{1}{c}{ Indikator } & Rata-rata \\
\hline Kejelasan bahasa & 82 \\
\hline Penguasaaan materi & 78 \\
\hline Pemahaman & 75 \\
\hline Kemampuan menjawab pertanyaan & 83 \\
\hline Kepercayaan diri & 87 \\
\hline Rata-rata Keseluruhan & 81 \\
\hline
\end{tabular}

Berdasarkan Tabel 3 di atas menunjukkan bahwa rata-rata kompetensi keterampilan mahasiswa menggunakan Geometer's Sketchpad pada pembelajaran Geometri Transformasi sebesar 81 dan berkategori sangat baik. Pada aspek bahasa menunjukkan bahwa mahasiswa dalam menjelaskan meteri menggunakan Geometer's Sketchpad sudah menggunakan bahasa yang sangat jelas dan dapat menjangkau ruang kelas dengan rata-rata sebesar 82. Sedangkan pada aspek penguasaan materi, mahasiswa mampu menguasai materi dan mempresentasikannya secara baik dengan rata-rata skor 78.

Kemudian pada aspek pemahaman, mahasiswa mampu menggunakan alur pemikiran yang sesuai dengan langkah-langkah penyelesaian masalah geometri transformasi dengan sangat baik dengan rata-rata 75 . Hal ini ditunjukkan dengan penjelasan yang tidak bermakna ganda atau penjelasan yang tidak membingungkan baik pada saat menyampaikan materi maupun menjawab pertanyaan mahasiswa lainnya. Namun demikian, penggunaan Geometer's Sketchpad perlu lebih dilatih lagi sehingga

Mohammad Syaifuddin, Reni Dwi Susanti, Rizal Dian Azmi, Kompetensi Mahasiswa Pada Pembelajaran Matematika Menggunakan Geometer's Sketchpad dengan Authentic Assessment 
mahasiswa menjadi lebih terampil dalam menggunakannya. Phonguttha (2008) juga mengemukakan bahwa untuk menerapkan Geometer's Sketchpad diperlukan waktu yang lebih lama dari pembelajaran konvensional. Pada aspek kemampuan menjawab pertanyaan, ketika ada mahasiswa lain yang bertanya terkait dengan apa yang dijelaskan, mahasiswa dapat menjawab dan menjelaskan apa yang ditanyakan dengan baik dan bisa diterima penjelasannya oleh penanya. Selanjutnya untuk aspek kepercayaan diri, mahasiswa yang melakukan presentasi juga sangat menguasai materi tersebut sehingga merasa sangat percaya diri akan apa yang dijelaskan. Ini juga dijelaskan oleh Phonguttha (2008) bahwa siswa dapat membuat visualisasi dari apa yang dipelajari dan berinteraksi dengan lingkungan belajarnya, yang artinya Geometer's Sketchpad dapat membuat siswa mengerti matematika dengan efisien.

\section{SIMPULAN}

Penggunaan Geometer's Sketchpad dengan Authentic Assessment sangat membantu mahasiswa dalam proses perkuliahan baik dalam aspek sikap, pemahaman konsep, dan keterampilan. Sikap dan respon mahasiswa baik dalam pembelajaran matematika menggunakan Geometer's Sketchpad dengan Authentic Assessment. Demikian pula pada kompetensi keterampilan dalam menggunakan media tersebut sehingga pemahaman konsep mahasiswa menjadi lebih baik. Pemahaman konsep matematika mahasiswa yang menggunakan Geometer's Sketchpad dengan Authentic Assessment lebih baik dibandingkan dengan mahasiswa yang tanpa digunakan media Geometer's Sketchpad dan Authentic Assessment. Oleh karena itu, diharapkan Geometer's Sketchpad dan penilaian Authentic Assessment dapat digunakan dalam pembelajaran pada materi yang bersesuaian dengan media tersebut agar kompetensi mahasiswa menjadi lebih baik.

\section{DAFTAR PUSTAKA}

Asmawati. (2019). Penggunaan Aplikasi Software Geometer's Sketchpad pada Pembelajaran Matematika untuk Memahamkan Konsep Transformasi Mahasiswa. Jurnal Pendidikan Matematika : Judika Education. Volume 2, Nomor 1

Azim, S., \& Khan, M. (2012). Authentic assessment: An instructional tool to enhance students learning. Academic Research International, 2(May), 314-320.

Bakar, K. A., Tarmizi, R. A., Ayub, A. F. M., \& Yunus, A. S. M. (2009). Effect of utilizing Geometer' s Sketchpad on performance and mathematical thinking of secondary mathematics learners: An initial exploration. International Journal of Education and Information Technologies, 3(1), 20-27.

Becker, H. (1991). How Computers are Used in United States Schools: Basic Data from the 1989 I.E.A. Computers in Education Survey. Journal of Educational Computing Research, 7(4), 385-406. https://doi.org/10.2190/P2UT-R3U3-FK1LB89L

Dimakos, G., \& Zarani, N. (2010). The Influence Of The Geometer's Sketchpad On The Geometry Achievement Of Greek School Students G. Dimakos, N. Zaranis. The Teaching of Mathematics, XIII(2), 113-124.

Eu, L. K. (2013). Impact Of Geometer' s Sketchpad On Students Achievement In Graph Functions, 1.

Frey, B. B., Schmitt, V. L., \& Allen, J. P. (2012). Defining Authentic Classroom Assessment - Practical Assessment, Research \&amp; Evaluation. Practical Assessment, Research \& Evaluation, 17(2), 1-18. https://doi.org/10.1002/tl.7401 
Hodgman, M. R. (2014). Using Authentic Assessments to Better Facilitate Teaching and Learning: The Case for Student Portfolios, 4(3), 59-65. https://doi.org/10.5296/jse.v4i3.6149

Idris, N. (2007). The effect of geometers' sketchpad on the performance in geometry of Malaysian students' achievement and their van Hiele geometric thinking. Malaysian Journal of Mathematical Sciences, 1(2), 169-180.

Idris, N. (2009). The Impact of Using Geometers' Sketchpad on Malaysian Students' Achievement and Van Hiele Geometric Thinking. Journal of Mathematics Education, 2(2), 94-107.

Jahanian, R. (2012). Educational Evaluation: Functions and Applications in Educational Contexts. International Journal of Academic Research in Economics and Management Sciences, 1(2), 253-257.

Khairiree, K. (1994). Connecting Geometry, Algebra and Calculus with The Geometer 's Sketchpad ( GSP ): Thailand Perspective.

Kintoko, Sujadi, I., \& Saputro, D. R. S. (2015). Pengembangan Media Pembelajaran Matematika Berbantuan Komputer Dengan Lectora Authoring Tools Pada Materi Bangun Ruang Sisi Datar Kelas VIII SMP / MTs. Jurnal Elektronik Pembelajaran Matematika, 3(2), 167-178.

Phonguttha, R., Tayraukham, S., \& Nuangchalerm, P. (2008). Comparisons of mathematics achievement, attitude towards mathematics and analytical thinking between using the geometer's sketchpad program as media and conventional learning activities. In IMSCI 2008 - 2nd International Multi-Conference on Society, Cybernetics and Informatics, Proceedings. https://doi.org/10.2139/ssrn.1285446

Section, C., \& Alam, S. (2010). Authentic Assessment and Pedagogical Strategies in Higher Education Chan Yuen Fook and Gurnam Kaur Sidhu Faculty of Education , University Technology MARA ,. Social Sciences, 6(2), 153-161. https://doi.org/10.3844/jssp.2010.153.161

Syamsuduha, D. (2011). Pengaruh Pembelajaran Kooperatif Berbantuan Program Geometer' s Sketchpad Terhadap Peningkatan Kemampuan Berpikir Kritis, (3), 978-979.

Tieng, P. G., \& Eu, L. K. (2014). Improving Students' Van Hiele Level of Geometric Thinking Using Geometer's Sketchpad. Malaysia Online Journal of Educational Techology, 2(3), 20-31.

$\mathrm{Wu}, \mathrm{H} .-\mathrm{H}$. (2012). The Journal of Mathematics Education at Teachers College is a publication of the Program in Mathematics and Education at Teachers College Columbia University in the City of New York. Journal of Mathematics Education at Teachers College, 3, 6-18. 